\title{
OPEN Gibberellic acid and nitrogen efficiently protect early seedlings growth stage from salt stress damage in Sorghum
}

\author{
Adam Yousif Adam Ali ${ }^{1,2,6}$, Muhi Eldeen Hussien Ibrahim ${ }^{1,3,6}$, Guisheng Zhou ${ }^{1 凶}$, \\ Nimir Eltyb Ahmed Nimir ${ }^{1,4}$, Aboagla Mohammed Ibrahim Elsiddig ${ }^{1}$, \\ Xiurong Jiao ${ }^{1}$, Guanglong Zhu ${ }^{1}$, Ebtehal Gabralla Ibrahim Salih ${ }^{1,5}$, \\ Mohamed Suliman Eltyeb Suliman Suliman ${ }^{1,4}$ \& Safiya Babiker Mustafa Elradi ${ }^{1,4}$
}

Salinity one of environmental factor that limits the growth and productivity of crops. This research was done to investigate whether $\mathrm{GA}_{3}(0,144.3,288.7$ and $577.5 \mu \mathrm{M})$ and nitrogen fertilizer $(0,90$ and $\left.135 \mathrm{~kg} \mathrm{~N} \mathrm{ha}^{-1}\right)$ could mitigate the negative impacts of $\mathrm{NaCl}(0,100$, and $200 \mathrm{mM} \mathrm{NaCl})$ on emergence percentage, seedling growth and some biochemical parameters. The results showed that high salinity level decreased emergence percentage, seedling growth, relative water content, chlorophyll content (SPAD reading), catalase (CAT) and peroxide (POD), but increased soluble protein content, superoxide dismutase (SOD) activity and malondialdehyde (MDA) content. The SOD activity was decreased by nitrogen. However, the other measurements were increased by nitrogen. The interactive impact between nitrogen and salinity was significant in most parameters except EP, CAT and POD. The seedling length, dry weight, fresh weight, emergence percentage, $P O D$, soluble protein and chlorophyll content were significantly affected by the interaction between $\mathrm{GA}_{3}$ and salinity. The $\mathrm{GA}_{3}$ and nitrogen application was successful mitigating the adverse effects of salinity. The level of 144.3 and $288.7 \mu \mathrm{m} \mathrm{GA}_{3}$ and the rate of 90 and $135 \mathrm{~kg} \mathrm{~N} \mathrm{ha}^{-1}$ were most effective on many of the attributes studied. Our study suggested that $\mathrm{GA}_{3}$ and nitrogen could efficiently protect early seedlings growth from salinity damage.

Salinity is an essential environmental stress that affects plant growth and causes limitations of crop production in the desert and semi-desert areas in the world ${ }^{3,4}$. Worldwide, there are about 95 million ha from whole world land, 45 million ha of the irrigated area were affected by salinity. Moreover, due to increment of salinity about 1.5 million ha are become out of production ${ }^{5}$.

Salinity stress can significantly inhibit germination and seedling growth, decrease many physiological processes and ultimately reduce crop productivity by causing osmotic stress and/or toxicity of ions as well as by reducing the uptake of important ions such as calcium and potassium ${ }^{6}$. Crop plants can suffer from salinity stress at all growth stages, but germination and early plant stage are known to be more sensitive for most plant species $^{7,8}$. Salinity stress affect all growth stages, but germination and early seedling stage are known to be more sensitive to salinity, causing significantly inhibited germination and seedling growth and ultimately decreased crop productivity through osmotic stress and ion toxicity such as $\mathrm{Na}^{+}$and $\mathrm{Cl}^{-}$, as well as throught reduced absorption of important nutrients such as $\mathrm{Ca}^{+2}$ and $\mathrm{K}^{+6,9}$.

Fertilization is an effective way to supply nutrients for plants, and it is also an important factor to improve the yield and quality of plants ${ }^{10}$. As compared with other nutrients, nitrogen $(\mathrm{N})$ is required most consistently in larger amounts for crop production ${ }^{11}$. $\mathrm{N}$ fertilization has a significant impact on plant growth, development, yield components, and quality, and its effective use to can enhance crop yield in agricultural systems ${ }^{1}$. Saline

\footnotetext{
${ }^{1}$ Joint International Research Laboratory of Agriculture and Agri-Product Safety of the Ministry of Education of China, Yangzhou University, Yangzhou 225009, China. ${ }^{2}$ Department of Agronomy, Faculty of Agricultural and Environmental Science, University of Gadarif, Al Qadarif, Sudan. ${ }^{3}$ Department of Agronomy, College of Agricultural Studies, Sudan University of Science and Technology, Khartoum 13311, Sudan. ${ }^{4}$ Faculty of Agriculture, University of Khartoum, 11115 Khartoum, Sudan. ${ }^{5}$ Faculty of Forestry, University of Khartoum, Khartoum, Sudan. ${ }^{6}$ These authors contributed equally: Adam Yousif Adam Ali and Muhi Eldeen Hussien Ibrahim. ${ }^{\square}$ email: gszhou@yzu.edu.cn
} 


\begin{tabular}{|c|c|c|c|c|c|c|c|c|c|c|c|}
\hline \multirow[b]{2}{*}{$\begin{array}{l}\text { Source of } \\
\text { variance }\end{array}$} & \multicolumn{11}{|l|}{ F value } \\
\hline & $\begin{array}{l}\text { Emergence } \\
\text { percentage }\end{array}$ & Seedling length & Fresh weight & Dry weight & RWC & $\begin{array}{l}\text { Chlorophyll } \\
\text { content }\end{array}$ & Protein content & SOD & CAT & POD & MDA \\
\hline Nitrogen $(\mathrm{N})$ & $43.0^{* *}$ & $148.7^{\star * *}$ & $388.6^{\star * *}$ & $2389.1^{\star *}$ & $151.2^{\star *}$ & $127.2^{\star *}$ & $176.7^{* *}$ & $181.1^{\star *}$ & $9.69^{*}$ & $5.5^{\star}$ & $171.3^{* *}$ \\
\hline Salinity (S) & $9.74^{* *}$ & $297.89^{* * *}$ & $97.4^{* *}$ & $154.5^{\star \star}$ & $14.3^{* *}$ & $392.4^{\star \star}$ & $26.0^{* *}$ & $8.2^{\star *}$ & $1.68^{\star}$ & $4.8^{\star}$ & $20.1^{\star *}$ \\
\hline $\mathrm{N} \times \mathrm{S}$ & $0.52^{\mathrm{ns}}$ & $2.77^{\star}$ & $9.5^{\star *}$ & $54.0^{* *}$ & $3.0^{*}$ & $33.2^{* *}$ & $7.2^{* *}$ & $5.0^{* *}$ & $0.20^{\mathrm{ns}}$ & $1.5^{\mathrm{ns}}$ & $1.4^{*}$ \\
\hline $\begin{array}{l}\text { Gibberellic acid } \\
\text { (G) }\end{array}$ & $0.56^{\mathrm{ns}}$ & $135.63^{\star *}$ & $3.6^{*}$ & $35.2^{* *}$ & $2.1^{\mathrm{ns}}$ & $2.3^{*}$ & $63.3^{\mathrm{ns}}$ & $15.1^{* *}$ & $17.7^{* *}$ & $74.4^{\star \star}$ & $135.8^{\star *}$ \\
\hline $\mathrm{N} \times \mathrm{G}$ & $2.26^{*}$ & $7.79^{* *}$ & $3.0^{*}$ & $210.6^{*}$ & $3.3^{* *}$ & $1.2^{\mathrm{ns}}$ & $54.4^{* *}$ & $3.6^{*}$ & $0.27^{\mathrm{ns}}$ & $11.8^{* *}$ & $9.2^{\mathrm{ns}}$ \\
\hline $\mathrm{S} \times \mathrm{G}$ & $2.21^{*}$ & $2.70^{*}$ & $0.96^{\mathrm{ns}}$ & $23.0^{* *}$ & $1.6^{\mathrm{ns}}$ & $2.9^{*}$ & $4.7^{\star *}$ & $4.4^{\mathrm{ns}}$ & $2.6^{*}$ & $3.9^{* *}$ & $5.8^{* *}$ \\
\hline $\mathrm{N} \times \mathrm{S} \times \mathrm{G}$ & $1.09^{\text {ns }}$ & $1.09^{\text {ns }}$ & $2.05 \mathrm{~ns}$ & $2.3^{\text {ns }}$ & $2.3 \mathrm{~ns}$ & $5.2^{\text {ns }}$ & $0.5^{\text {ns }}$ & $0.6^{\mathrm{ns}}$ & $0.5^{\mathrm{ns}}$ & $1.0^{\mathrm{ns}}$ & $0.3^{\text {ns }}$ \\
\hline
\end{tabular}

Table 1. Summary of analysis of variance (ANOVA table) for emergence percentage, seedling length, fresh weight, dry weight, Chlorophyll content (SPAD reding), relative water content (RWC), protein content, superoxide dismutase (SOD), catalase (CAT), peroxide (POD), and malondialdehyde (MDA) of sorghum seedlings as effected by salinity, nitrogen and gibberellic acid and their interactions. $n s$ not significant. ${ }^{\star}$ Significant at the 0.05 probability level. ${ }^{* *}$ Significant at the 0.01 probability level. ${ }^{* *}$ Significant at the 0.001 probability level.

soil is characterized by an imbalance of essential nutrients in the soil and leads to decreased absorption of these elements, especially nitrogen, phosphorus, and potassium in the root system. Previous studies have observed that the relation between salinity and mineral nutrition is very complicated and not well understood ${ }^{7}$. Zhang et al. ${ }^{12}$ reported that the application of fertilizer could balance the nutrients in the cytosol and improve nutrient absorption and utilization. Further, saline soils usually increase osmotic pressure in the root medium and reduce the responses of plant to fertilizer application, which is the main reason for decreased photosynthesis in plant under salinity stress ${ }^{7}$.

Gibberellins is one of the major plant hormones and an efficient and broad-spectrum plant growth regulator. Gibberellins have reported being a promoter for plant growth under salinity conditions, which can reduce seed dormancy, improve plant gene expression, enhance the synthesis of hydrolase, repair injured cell membranes, and increase seed vitality ${ }^{13}$. In current times, many investigations have revealed that the treatment of exogenous gibberellic acid $\left(\mathrm{GA}_{3}\right)$ can significantly increase seed germination, increase the salt tolerance of seeds, and mitigate the inhibition of salt on seedling growth ${ }^{13,14}$.

Sorghum [Sorghum bicolor (L.) Moench] is one of the main crops because of its high productivity and high nutritive value. It can adapt to different environmental conditions, especially in arid and semi-arid areas ${ }^{15}$. Sorghum is considered moderately tolerant to soil salinity. Germination and seedling stage of sorghum grown on salinity soils are essential for the final production and yield ${ }^{16}$.

The seedling stage is important for plant life and crop production. For good plant establishment and great production, alleviating ways should be developed to improve early plant growth under abiotic stress. However, to our knowledge, there are little research on the impacts of external $\mathrm{GA}_{3}$ application and nitrogen application on seedling characteristics and anti-oxidative defense system of sorghum under salinity conditions. Many reports have focused on the alleviation impacts of gibberellic acid on salinity stress. In this study, we hypothesized that seed pre-soaking by $\mathrm{GA}_{3}$, and soil treated by nitrogen fertilizer could improve the crop establishment through increase the seedling emergence, and improve seedling growth characteristics of sorghum. Therefore, this study was done to examine the impacts of nitrogen application, gibberellic acid and sodium chloride on the morphological attitudes and the activities of antioxidant enzyme of sorghum seedling.

\section{Results}

The ANOVA table indicated that salinity, nitrogen, gibberellic acid and their interactions produced different effects on most parameters, including seedling emergence percentage, seedling growth characteristics, relative water content, chlorophyll content (SPAD reading), protein content, the activities of superoxide dismutase (SOD), peroxide (POD), catalase (CAT), and malondialdehyde (MDA) content (Table 1).

Emergence percentage. Emergence percentage (EP) increased with application of nitrogen and gibberellic acid $\left(\mathrm{GA}_{3}\right)$. At the high salinity level of $200 \mathrm{mM} \mathrm{NaCl}$, EP was increased by $11.78 \%$ when the plants were treated with $288.7 \mu \mathrm{M} \mathrm{GA}_{3}$ as compared with control $\left(0 \mu \mathrm{M} \mathrm{GA}_{3}\right)$ (Table 2). In the interaction between nitrogen and gibberellic acid, the highest EP (84.44\%) value was determined on the interaction between $135 \mathrm{~kg} \mathrm{~N} \mathrm{ha}^{-1}$ with $288.7 \mu \mathrm{M} \mathrm{GA}_{3}$, while the lowest emergence percentage value was recorded at the $0 \mathrm{~kg} \mathrm{~N}^{-1}$ with $288.7 \mu \mathrm{M}$ $\mathrm{GA}_{3}$. Emergence seedling percentage was reduced with increased $\mathrm{NaCl}$ salinity level (Table 3 ).

Seedling length. The nitrogen and $\mathrm{GA}_{3}$ treatment affected seedling length positively. At the highest salinity level of $200 \mathrm{mM} \mathrm{NaCl}$, seedling length was increased by $15.4 \%$ and $13.6 \%$ when the seeds were treated with 135 and $90 \mathrm{~kg} \mathrm{~N} \mathrm{ha}^{-1}$ respectively, as compared with $0 \mathrm{mM} \mathrm{NaCl}$ (Fig. 1a). However, at the same salinity level, as compared with control of gibberellic acid $\left(0 \mu \mathrm{M} \mathrm{GA}_{3}\right)$, the levels of 577.5 and $144.3 \mu \mathrm{M} \mathrm{GA}$ increased the seedling length by $53.0 \%$ and $32.3 \%$ respectively. The seedling length decreased gradually with increased salinity (Fig. 1b). For the interaction between nitrogen and gibberellic acid, the highest seedling length $(24.98 \mathrm{~cm})$ value 


\begin{tabular}{|c|c|c|c|c|c|c|}
\hline Salinity (mM NaCl) & $\begin{array}{l}\text { Gibberellic acid }(\mu \mathrm{M} \\
\left.\mathrm{GA}_{3}\right)\end{array}$ & $\begin{array}{l}\text { Emergence percentage } \\
(\%)\end{array}$ & Fresh weight ( g plant $^{-1}$ ) & Dry weight $\left(\mathbf{m g ~ p l a n t}^{-1}\right)$ & $\begin{array}{l}\text { Protein content (mg } \\
\left.\mathrm{g}^{-1} \mathrm{FW}\right)\end{array}$ & MDA $\left(\mu \mathrm{g} \mathrm{g}^{-1} \mathrm{FW}\right)$ \\
\hline \multirow{4}{*}{0} & 0 & $67.78 \mathrm{~cd}$ & $0.25 b$ & $84.90 \mathrm{c}$ & $16.78 \mathrm{e}$ & $22.94 \mathrm{~g}$ \\
\hline & 144.3 & $80.01 \mathrm{a}$ & $0.28 \mathrm{ab}$ & $104.4 \mathrm{a}$ & $19.79 \mathrm{~d}$ & $26.37 \mathrm{fg}$ \\
\hline & 288.7 & $75.25 \mathrm{~b}$ & $0.30 \mathrm{a}$ & $95.14 \mathrm{~b}$ & 17.81de & $28.35 \mathrm{efg}$ \\
\hline & 577.5 & $80.56 a$ & $0.27 \mathrm{ab}$ & $69.01 \mathrm{~d}$ & 18.89de & $35.15 \mathrm{bcd}$ \\
\hline \multirow{4}{*}{100} & 0 & $65.56 \mathrm{~d}$ & $0.14 \mathrm{e}$ & $47.84 \mathrm{~h}$ & $21.68 \mathrm{~d}$ & $24.45 \mathrm{f}$ \\
\hline & 144.3 & $73.89 \mathrm{bc}$ & $0.18 \mathrm{de}$ & $65.56 \mathrm{~d}$ & $23.62 \mathrm{dc}$ & $28.08 \mathrm{e}$ \\
\hline & 288.7 & $73.33 \mathrm{bc}$ & $0.21 \mathrm{c}$ & $78.77 \mathrm{c}$ & $24.01 \mathrm{c}$ & $28.65 \mathrm{e}$ \\
\hline & 577.5 & $71.11 \mathrm{c}$ & $0.19 \mathrm{~d}$ & $71.22 \mathrm{~d}$ & $20.35 \mathrm{~d}$ & $31.87 \mathrm{c}$ \\
\hline \multirow{4}{*}{200} & 0 & $63.33 \mathrm{e}$ & $0.08 \mathrm{~g}$ & $36.31 \mathrm{~g}$ & $27.72 \mathrm{~b}$ & 33.41cd \\
\hline & 144.3 & $66.11 \mathrm{~d}$ & $0.11 \mathrm{f}$ & $45.92 \mathrm{f}$ & $25.65 \mathrm{c}$ & $37.7 \mathrm{~b}$ \\
\hline & 288.7 & $70.89 \mathrm{c}$ & $0.09 \mathrm{~g}$ & $47.35 \mathrm{f}$ & $32.34 \mathrm{a}$ & $40.25 \mathrm{ab}$ \\
\hline & 577.5 & $66.67 \mathrm{~d}$ & $0.12 \mathrm{f}$ & $51.41 \mathrm{e}$ & $30.23 \mathrm{ab}$ & $44.71 \mathrm{a}$ \\
\hline
\end{tabular}

Table 2. Impacts of interaction between different salinity levels and different gibberellic acid levels on emergence percentage, fresh weight, dry weight, protein content and MDA content on sorghum seedlings. Within the same column, means followed by the different letters are statistically different at $P \leq 0.05$.

\begin{tabular}{|c|c|c|c|c|c|c|c|c|c|}
\hline \begin{tabular}{|l}
$\begin{array}{l}\text { Nitrogen } \\
\left(\mathrm{kg}^{-1} \mathrm{ha}^{-1}\right)\end{array}$ \\
\end{tabular} & $\begin{array}{l}\text { Gibberellic acid } \\
\left(\mu \mathrm{M} \mathrm{GA}_{3}\right)\end{array}$ & \begin{tabular}{|l} 
Emergence \\
percentage (\%)
\end{tabular} & $\begin{array}{l}\text { Seedling length } \\
\mathrm{cm})\end{array}$ & $\begin{array}{l}\begin{array}{l}\text { Fresh weight (g } \\
\text { plant }^{-1} \text { ) }\end{array} \\
\end{array}$ & $\begin{array}{l}\text { Dry weight (mg } \\
\text { plant }^{-1} \text { ) }\end{array}$ & RWC (\%) & $\begin{array}{l}\text { Protein (mg } \\
\left.\mathrm{g}^{-1} \mathrm{FW}\right)\end{array}$ & $\begin{array}{l}\text { POD }\left(\mu \mathrm{g} \mathrm{g}^{-1}\right. \\
\text { FW })\end{array}$ & $\begin{array}{l}\text { SOD }\left(\mu g^{-1}\right. \\
\text { FW) }\end{array}$ \\
\hline \multirow{4}{*}{$0 \mathrm{~N}$} & 0 & $79.22 \mathrm{~b}$ & $15.50 \mathrm{~g}$ & $0.070 \mathrm{f}$ & $19.62 \mathrm{~h}$ & $34.36 \mathrm{f}$ & $18.68 \mathrm{~cd}$ & $24.98 \mathrm{f}$ & $10.73 \mathrm{f}$ \\
\hline & 144.3 & $82.22 \mathrm{ab}$ & $24.32 \mathrm{bc}$ & 0.096ef & 24.14ef & $31.28 \mathrm{fg}$ & $17.74 \mathrm{~cd}$ & $40.53 \mathrm{~d}$ & $13.76 \mathrm{e}$ \\
\hline & 288.7 & $47.78 \mathrm{e}$ & $23.49 \mathrm{c}$ & $0.120 \mathrm{e}$ & $30.04 \mathrm{e}$ & $32.44 \mathrm{fg}$ & $17.19 \mathrm{~d}$ & $28.42 \mathrm{ef}$ & 12.91ef \\
\hline & 577.5 & $77.22 \mathrm{bc}$ & $25.54 \mathrm{~b}$ & $0.072 \mathrm{f}$ & $20.74 \mathrm{f}$ & $32.66 \mathrm{fg}$ & $17.77 \mathrm{~cd}$ & $31.02 \mathrm{e}$ & 14.19de \\
\hline \multirow{4}{*}{$90 \mathrm{~N}$} & 0 & $60.21 \mathrm{~d}$ & $16.39 \mathrm{f}$ & $0.137 \mathrm{de}$ & 51.70de & $96.05 \mathrm{~b}$ & $31.60 \mathrm{~b}$ & 25.94ef & $13.90 \mathrm{e}$ \\
\hline & 144.3 & 60.35d & $17.48 \mathrm{ef}$ & $0.155 \mathrm{~d}$ & $49.17 \mathrm{de}$ & $115.49 a$ & 34.64ab & 36.41de & $17.89 \mathrm{~d}$ \\
\hline & 288.7 & $80.56 \mathrm{ab}$ & $18.79 \mathrm{e}$ & $0.137 \mathrm{de}$ & $54.35 \mathrm{~d}$ & $83.08 \mathrm{~cd}$ & $36.50 \mathrm{a}$ & 37.54de & $22.01 \mathrm{~b}$ \\
\hline & 577.5 & $58.89 \mathrm{de}$ & $20.89 \mathrm{~d}$ & $0.209 \mathrm{c}$ & $48.45 \mathrm{e}$ & $83.59 \mathrm{~cd}$ & 33.76ab & $32.21 \mathrm{de}$ & $26.58 \mathrm{a}$ \\
\hline \multirow{4}{*}{$135 \mathrm{~N}$} & 0 & $73.33 c$ & $18.02 \mathrm{e}$ & $0.268 \mathrm{cb}$ & $97.73 \mathrm{c}$ & $74.55 \mathrm{e}$ & $20.22 \mathrm{~cd}$ & $108.60 \mathrm{c}$ & $19.53 c$ \\
\hline & 144.3 & $77.22 b c$ & $24.98 \mathrm{bc}$ & $0.301 \mathrm{ab}$ & $142.57 \mathrm{a}$ & 81.73d & $18.68 \mathrm{~cd}$ & $85.48 \mathrm{bc}$ & $21.34 \mathrm{bc}$ \\
\hline & 288.7 & $84.44 \mathrm{a}$ & $23.73 c$ & $0.343 \mathrm{a}$ & 136.86ab & $81.45 \mathrm{~d}$ & $21.16 \mathrm{c}$ & $155.20 \mathrm{~b}$ & $20.76 \mathrm{bc}$ \\
\hline & \begin{tabular}{|l|}
577.5 \\
\end{tabular} & $72.78 \mathrm{c}$ & $28.01 \mathrm{a}$ & $0.299 \mathrm{~b}$ & $122.44 \mathrm{~b}$ & \begin{tabular}{|l|}
$86.91 c$ \\
\end{tabular} & 19.94cd & 185.70a & $18.74 \mathrm{~cd}$ \\
\hline
\end{tabular}

Table 3. Effects of different nitrogen rates and different gibberellic acid $\left(\mathrm{GA}_{3}\right)$ levels on emergence percentage, seedling length, fresh weight, dry weight, relative water content (RWC) protein content $\left(\mathrm{mg} \mathrm{g}^{-1} \mathrm{FW}\right)$, SOD, and POD of sorghum seedlings. Different letters in the same column show significant differences at the 0.05 probability level.

was determined on $135 \mathrm{~kg} \mathrm{~N} \mathrm{ha}^{-1}$ with $144.3 \mu \mathrm{M} \mathrm{GA}_{3}$, while the lowest seedling length value recorded at the $0 \mathrm{~kg} \mathrm{~N} \mathrm{ha}^{-1}$ with $0 \mu \mathrm{M} \mathrm{GA}_{3}$ (Table 3).

Fresh weight and dry weight. Fresh weight and dry weight was increased by $\mathrm{GA}_{3}$ and application of nitrogen, and decreased with increased salinity level (Table 2). However, at the high salinity level of $200 \mathrm{mM}$ $\mathrm{NaCl}$, as compared with $0 \mu \mathrm{M} \mathrm{GA}_{3}, 577.5 \mu \mathrm{M} \mathrm{GA}_{3}$ level increased fresh weight and dry weight by $50.0 \%$ and $41.6 \%$, respectively (Table 2). Moreover, for the interaction between nitrogen and $\mathrm{GA}_{3}$, the highest fresh weight $\left(0.343 \mathrm{~g} \mathrm{plant}^{-1}\right)$ and dry weight $\left(142.6 \mathrm{mg} \mathrm{plant}^{-1}\right)$ value were determined on the $135 \mathrm{~kg} \mathrm{~N} \mathrm{ha}^{-1}$ with 288.7 and $135 \mathrm{~kg} \mathrm{~N} \mathrm{ha}^{-1}$ with $144.3 \mu \mathrm{M} \mathrm{GA}_{3}$ respectively. While, the lowest fresh weight and dry weight were recorded at the $0 \mathrm{~kg} \mathrm{~N} \mathrm{ha}^{-1}$ with $0 \mathrm{~kg} \mathrm{~N} \mathrm{ha}^{-1}$ (Table 3). As compared with control of nitrogen, at the high salinity level, the rate of $135 \mathrm{~kg} \mathrm{~N} \mathrm{ha}^{-1}$ increased fresh weight and dry weight by $89.5 \%$ and $59.1 \%$ respectively (Table 4 ).

Chlorophyll content (SPAD reading). The chlorophyll content was decreased with increased salinity level. Chlorophyll content was improved by nitrogen application and $\mathrm{GA}_{3}$ amendment. At the high salinity level of $200 \mathrm{mM} \mathrm{NaCl}$, the rate of $90 \mathrm{~kg} \mathrm{~N} \mathrm{ha}^{-1}$ increased chlorophyll content by $35.0 \%$ as compared with $0 \mathrm{~kg} \mathrm{~N} \mathrm{ha}^{-1}$ (Fig. 2a). At the same salinity, the level of 288.7 and $144.3 \mu \mathrm{M} \mathrm{GA}_{3}$ had the highest chlorophyll content (17.62 and 17.19 respectively) (Fig. $2 \mathrm{~b}$ ). 

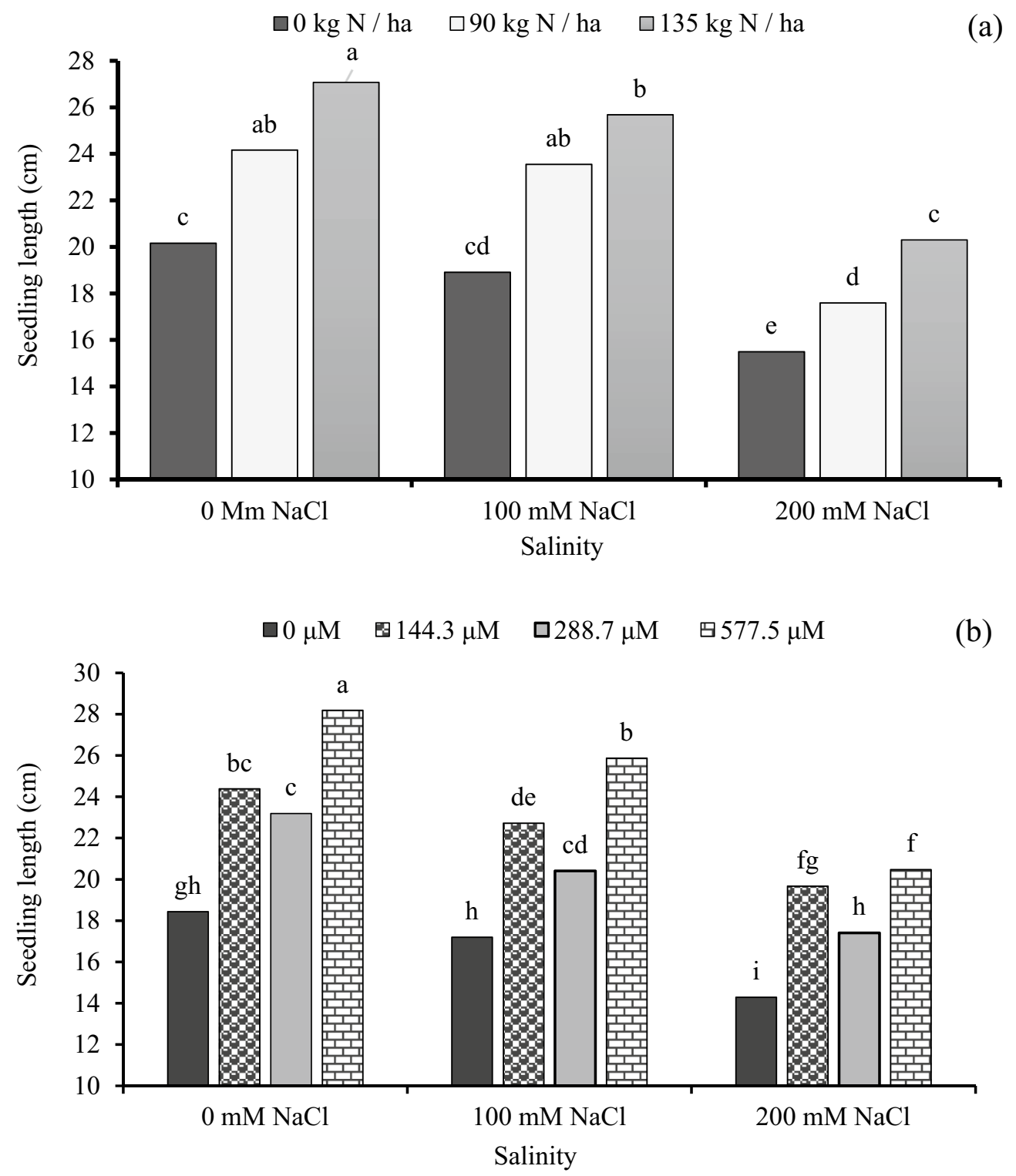

Figure 1. The effect of interaction between: (a) different concentrations of salinity $\times$ different concentrations of nitrogen and (b) different concentrations of salinity $\times$ different concentrations of gibberellic acid $\left(\mathrm{GA}_{3}\right)$ on seedling length $(\mathrm{cm})$ of sorghum seedling. Bars with different letters are significantly different at the 0.05 probability. Means were separated by the LSD test.

\begin{tabular}{|c|c|c|c|c|c|c|c|c|}
\hline $\begin{array}{l}\text { Salinity (mM } \\
\mathrm{NaCl})\end{array}$ & $\begin{array}{l}\text { Nitrogen (N } \\
\left.\mathrm{kg}^{-1} \mathrm{ha}^{-1}\right)\end{array}$ & $\begin{array}{l}\begin{array}{l}\text { Fresh weight }(\mathrm{g} / \\
\left.\text { plant }^{-1}\right)\end{array} \\
\end{array}$ & $\begin{array}{l}\text { Dry weight (mg/ } \\
\text { plant }^{-1} \text { ) }\end{array}$ & RWC (\%) & CAT $\left(\mu \mathrm{g} \mathrm{g}^{-1} \mathrm{FW}\right)$ & POD $\left(\mu \mathrm{g} \mathrm{g}^{-1} \mathrm{FW}\right)$ & \begin{tabular}{|l|} 
Protein $\left(\mathrm{mg} \mathrm{g}^{-1}\right.$ \\
FW)
\end{tabular} & $\begin{array}{l}\text { MDA ( } \mu \mathrm{g} \mathrm{g}^{-1} \\
\text { FW) }\end{array}$ \\
\hline \multirow{3}{*}{0} & 0 & $0.20 \mathrm{c}$ & $37.04 \mathrm{~d}$ & $85.86 \mathrm{c}$ & $59.24 \mathrm{bc}$ & $51.89 c$ & $13.47 \mathrm{~g}$ & $19.96 \mathrm{f}$ \\
\hline & 90 & $0.29 \mathrm{~b}$ & $83.82 \mathrm{ab}$ & $101.87 \mathrm{a}$ & $66.50 \mathrm{~b}$ & $62.08 \mathrm{~b}$ & $16.29 \mathrm{c}$ & $34.61 \mathrm{de}$ \\
\hline & 135 & $0.36 \mathrm{a}$ & $94.22 \mathrm{a}$ & $65.78 \mathrm{~d}$ & 74.11a & $77.25 \mathrm{a}$ & $31.77 \mathrm{e}$ & $36.99 \mathrm{ef}$ \\
\hline \multirow{3}{*}{100} & 0 & $0.12 \mathrm{~cd}$ & $30.05 \mathrm{e}$ & $82.72 \mathrm{c}$ & $48.77 \mathrm{~d}$ & $38.95 \mathrm{dc}$ & $22.10 \mathrm{e}$ & $32.47 \mathrm{de}$ \\
\hline & 90 & $0.15 \mathrm{~d}$ & $36.23 \mathrm{~d}$ & $92.78 \mathrm{~b}$ & $36.20 \mathrm{e}$ & $49.13 \mathrm{bc}$ & $30.16 \mathrm{~b}$ & $42.77 \mathrm{bc}$ \\
\hline & 135 & $0.34 \mathrm{ab}$ & $81.27 \mathrm{~b}$ & $59.69 \mathrm{~d}$ & $61.05 b c$ & $42.45 c$ & $38.12 \mathrm{c}$ & $53.14 \mathrm{e}$ \\
\hline \multirow{3}{*}{200} & 0 & $0.06 \mathrm{e}$ & $22.82 \mathrm{f}$ & $74.91 \mathrm{~cd}$ & $28.53 \mathrm{ef}$ & $27.90 \mathrm{e}$ & $17.90 \mathrm{~b}$ & $26.96 \mathrm{c}$ \\
\hline & 90 & $0.10 \mathrm{f}$ & 32.70de & $89.01 \mathrm{~b}$ & $37.21 \mathrm{e}$ & $33.26 \mathrm{~d}$ & $24.26 \mathrm{a}$ & $29.41 \mathrm{a}$ \\
\hline & 135 & $0.19 \mathrm{c}$ & $59.22 \mathrm{c}$ & $51.76 \mathrm{e}$ & $48.36 \mathrm{~d}$ & $31.50 \mathrm{de}$ & $28.07 \mathrm{bc}$ & $46.93 b$ \\
\hline
\end{tabular}

Table 4. Impacts of salinity and nitrogen on fresh weight, dry weight, relative water content (RWC), CAT, POD, protein content and MDA content on seedling of sorghum. Within the same column, means followed by the different letters are statistically different at $\mathrm{P} \leq 0.05$. 

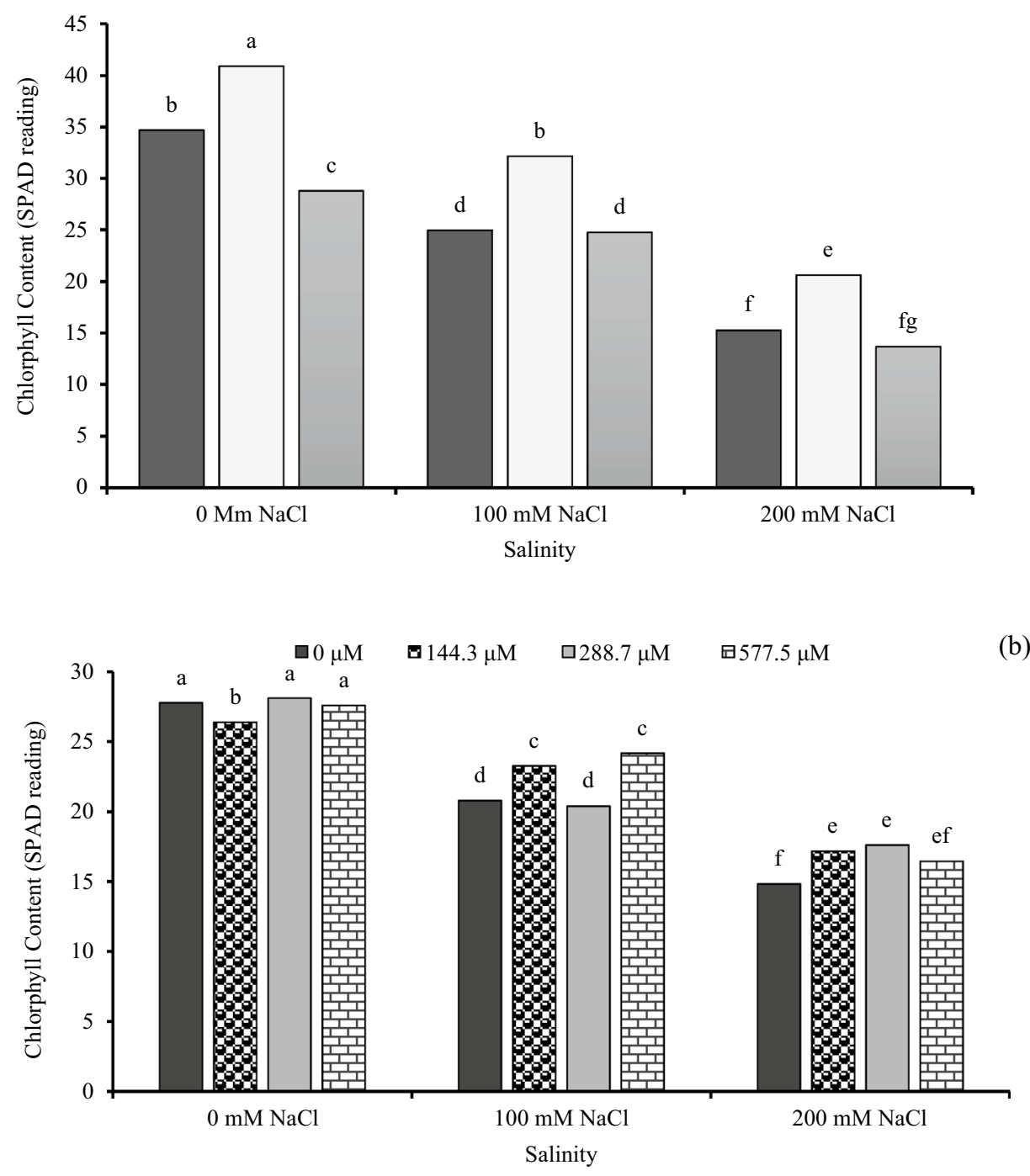

Figure 2. The effect of interaction between: (a) different concentrations of salinity $\times$ different concentrations of nitrogen and (b) different concentrations of salinity $\times$ different concentrations of gibberellic acid $\left(\mathrm{GA}_{3}\right)$ on chlorophyll content (SPAD reading). Bars with different letters are significantly different at the 0.05 probability. Means were separated by the LSD test.

Relative water content. Relative water content (RWC) was increased with nitrogen treatment and was decreased gradually with increased salinity. The interaction between high salinity level of the $200 \mathrm{mM} \mathrm{NaCl}$ with rate of $90 \mathrm{~kg} \mathrm{~N} \mathrm{ha}^{-1}$ increased RWC by $21.3 \%$ as compared with $200 \mathrm{mM} \mathrm{NaCl}$ plus $0 \mathrm{~kg} \mathrm{~N} \mathrm{ha}^{-1}$ (Table 2). In the interaction between nitrogen and $\mathrm{GA}_{3}$, the highest value of RWC $(115.5 \%)$ recorded at $90 \mathrm{~kg} \mathrm{~N} \mathrm{ha}^{-1}$ with 144.3 $\mu \mathrm{M} \mathrm{GA}_{3}$. Moreover, 288.7 $\mu \mathrm{M} \mathrm{GA}_{3}$ with $0 \mathrm{~kg} \mathrm{~N} \mathrm{ha}^{-1}$ recorded the lowest value of RWC (31.3\%) (Table 4).

Catalase and peroxidase activities. The catalase (CAT) and peroxidase (POD) activities were enhanced by nitrogen application and exogenous $\mathrm{GA}_{3}$, but decreased by increased salinity level. In the interaction between salinity and $\mathrm{GA}_{3}$, at the $200 \mathrm{mM} \mathrm{NaCl}$, the highest value of CAT and POD activities values were recorded at the $144.3 \mu \mathrm{M} \mathrm{GA}_{3}$ (Fig. 3a) and $577.5 \mu \mathrm{M} \mathrm{GA}_{3}$ (Fig. 3b) respectively. in the interaction between nitrogen and $\mathrm{GA}_{3}$, the highest value of POD activity $\left(185.7 \mu \mathrm{g} \mathrm{g}^{-1} \mathrm{FW}\right)$ was observed at $135 \mathrm{~kg} \mathrm{~N} \mathrm{ha}^{-1}$ with $577.5 \mu \mathrm{M} \mathrm{GA}_{3}$, while the lowest POD $\left(25.0 \mu \mathrm{g} \mathrm{g}^{-1} \mathrm{FW}\right)$ activity value showed at $0 \mu \mathrm{M} \mathrm{GA}_{3}$ plus $0 \mathrm{~kg} \mathrm{~N} \mathrm{ha}^{-1}$ (Table 3 ). At the high salinity level of $200 \mathrm{mM} \mathrm{NaCl}$, the $\mathrm{N}$ rates of 135 and $90 \mathrm{~kg} \mathrm{~N} \mathrm{ha}^{-1}$ increased CAT and POD activity by $69.5 \%$ and $22.2 \%$ respectively as compared with $0 \mathrm{~kg} \mathrm{~N} \mathrm{ha}^{-1}$ (Table 4).

Superoxide dismutase. Superoxide dismutase activity (SOD) was increased by salinity, nitrogen and $\mathrm{GA}_{3}$. The highest SOD activity value was recorded at the $200 \mathrm{mM} \mathrm{NaCl}$ with $90 \mathrm{~kg} \mathrm{~N} \mathrm{ha}^{-1}$, however the lowest SOD activity was recorded at $0 \mathrm{mM} \mathrm{NaCl}$ plus $0 \mathrm{~kg} \mathrm{~N} \mathrm{ha}^{-1}$ (Fig. 4a). In addition, the highest activity of SOD 

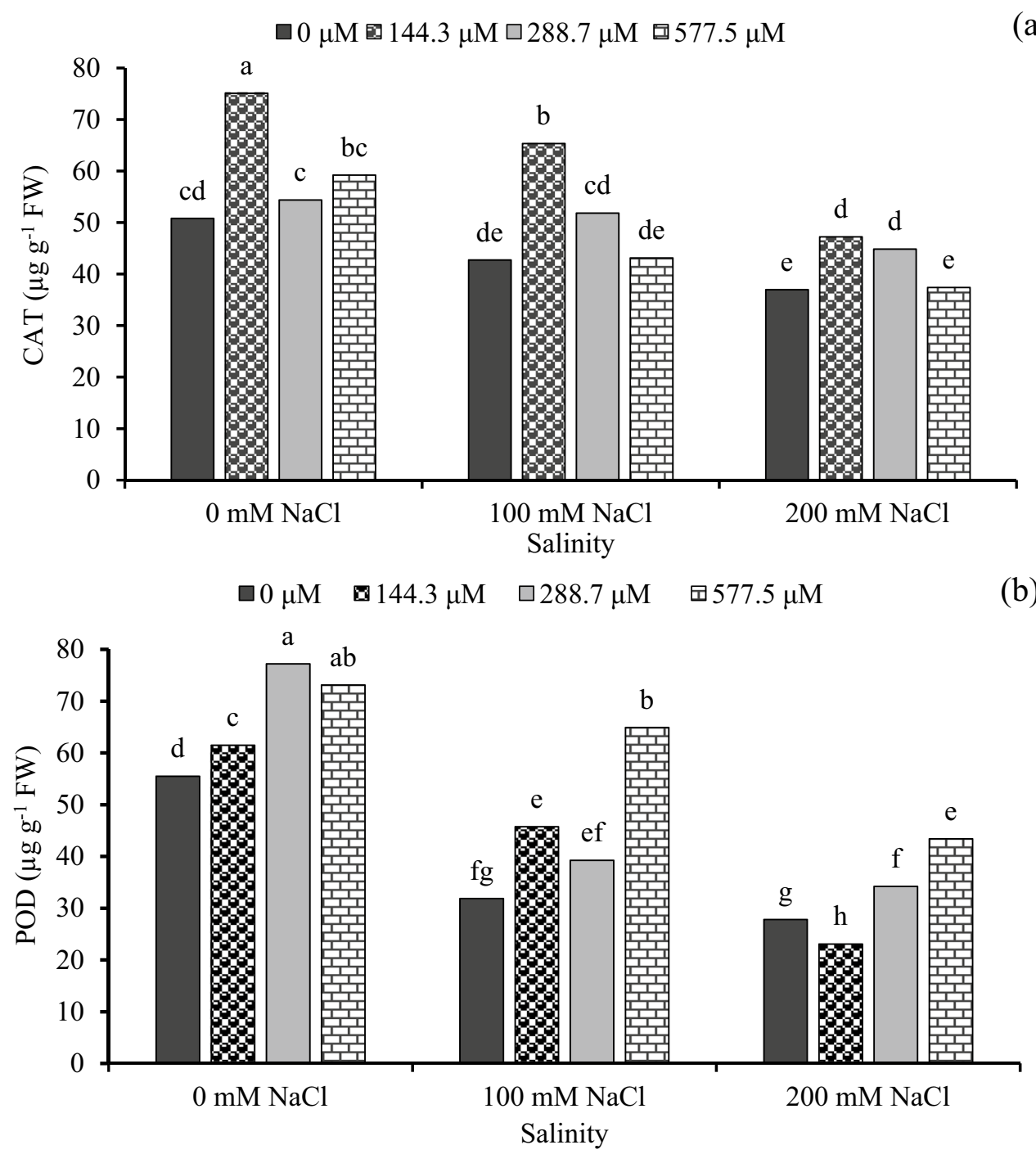

Figure 3. The effect of interaction between different concentrations of salinity $\times$ different concentrations of gibberellic acid $\left(\mathrm{GA}_{3}\right)$ on (a) catalase (CAT) and (b) and peroxidase (POD) activities of sorghum seedling. Bars with different letters are significantly different at the 0.05 probability. Means were separated by the LSD test.

(23.77 $\left.\mu \mathrm{g} \mathrm{g}^{-1} \mathrm{FW}\right)$ was recorded at $288.7 \mu \mathrm{M}+200 \mathrm{mM} \mathrm{NaCl}$ (Fig. 4b). Seeds treated with $90 \mathrm{~kg} \mathrm{~N}^{-1}$ plus $577.5 \mu \mathrm{M} \mathrm{GA}_{3}$ increased SOD activity by $147.7 \%$ as compared with $0 \mathrm{~kg} \mathrm{~N}^{-1}$ with $0 \mu \mathrm{M} \mathrm{GA}$ (Table 3 ).

Malondialdehyde and soluble protein content. The malondialdehyde content (MDA) and soluble protein content were increased with salinity, nitrogen rates and $\mathrm{GA}_{3}$ levels. The highest MDA content $\left(44.71 \mu \mathrm{g} \mathrm{g} \mathrm{g}^{-1}\right.$ FW) and soluble protein content $\left(32.3 \mathrm{mg} \mathrm{g}^{-1} \mathrm{FW}\right)$ were recorded at $200 \mathrm{mM} \mathrm{NaCl}$ plus $577.5 \mu \mathrm{M} \mathrm{GA}$ and $200 \mathrm{mM} \mathrm{NaCl}+288.7 \mu \mathrm{M} \mathrm{GA}_{3}$, respectively (Table 2). Moreover, the highest soluble protein content $\left(36.5 \mathrm{mg} \mathrm{g}^{-1}\right.$ FW) was recorded at $577 \mu \mathrm{M}$ plus $90 \mathrm{~kg} \mathrm{~N} \mathrm{ha}^{-1}$ (Table 3). As compared with the $0 \mathrm{mM} \mathrm{NaCl}+0 \mathrm{~kg} \mathrm{~N}^{-1}$, the rate of $90 \mathrm{~kg} \mathrm{~N} \mathrm{ha}^{-1}$ plus $200 \mathrm{mM} \mathrm{NaCl}$ increased soluble protein content and MDA content by $20.0 \%$ and $43.7 \%$, respectively (Table 4$)$.

\section{Discussion}

High salinity stress affects plant growth by changing their physiological parameters ${ }^{1}$. In this study, seedling emergence percentage and seedling growth (root and shoot length, fresh and dry weight) and relative water content were decreased with increased salinity. The reductions in emergence percentage might be due to the decrease in water uptake and enzyme activity caused by salinity ${ }^{17}$. Similar effects were shown in sweet sorghum ${ }^{17}$, wheat ${ }^{18}$, and forage sorghum ${ }^{19}$. In the present study, shoot and root length decreased as salinity level increased. The decline in root and shoot length and development might be due to ions toxicity or reduction in osmotic potential caused by decreased water uptake and nutrient absorption. The impacts of higher salinity on the root growth were more pronounced than shoot growth and caused the reductions in seedlings growth ${ }^{20,21}$. Some studies indicated that reduced growth of the plant due to the proportional increase of sodium ${ }^{21}$. Our results are in agreement with 

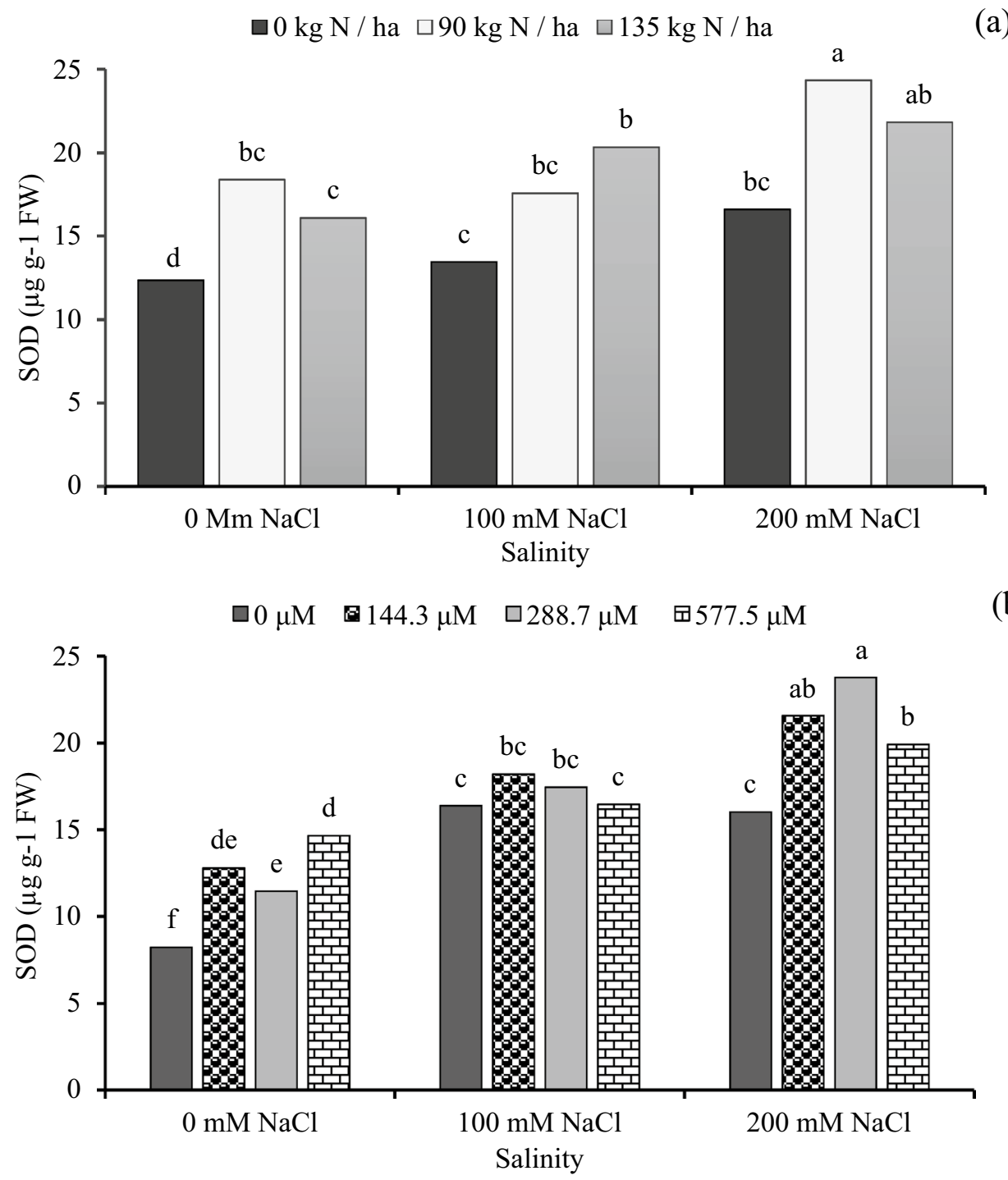

(b)

Figure 4. The effect of interaction between: (a) different concentrations of salinity $\times$ different concentrations of nitrogen and $(\mathbf{b})$ different concentrations of salinity $\times$ different concentrations of gibberellic acid $\left(\mathrm{GA}_{3}\right)$ on SOD of sorghum seedling. Bars with different letters are significantly different at the 0.05 probability. Means were separated by the LSD test.

Khan et al. ${ }^{22}$, Nimir et al. ${ }^{17}$ and Ibrahim et al. ${ }^{3}$. The reduced in fresh and dry weight at the salinity stress might be due to the lowest water absorption cause by physiological drought ${ }^{23,24}$. Our findings are in agreement with those of Dheeba et al. ${ }^{25}$, who reported that salinity reduced the fresh and dry weight of plants. Ibrahim et al. ${ }^{2}$ noted that the negative correlation between growth characteristics and salinity stress. The result of decreased in RWC under salinity stress similar with the findings of Ibrahim et al. ${ }^{21}$.

In this investigation, nitrogen application increased seedling emergence percentage, seedling growth and RWC, and alleviated the negative effects of salinity. The increase in emergence percentage by introgen is in agreement with Ibrahim et al. ${ }^{3}$ who reported that the lowest emergence percentage was achieved at the high salinity with the control of nitrogen. However, these findings are in disagreement with those of Fallahi and Khajeh ${ }^{26}$, who found that nirogen application had a negative effect on seed germination and emergence percentage under saline stress. The increase in seedling growth under salinity stress by nitrogen is in agreement with Ibrahim et al. ${ }^{3}$ and Xiong et al. ${ }^{27}$, who reported that nitrogen fertilizer significantly increased root and shoot length, fresh and dry weight under soil salinity conditions.

In the present study, $\mathrm{GA}_{3}$ treatment enhanced seedling emergence percentage, seedling growth and RWC. $\mathrm{GA}_{3}$ significantly affected emergence percentage, and alleviated the adverse impact of salinity stress by improving water uptake and increase cellular membrane plasticity ${ }^{28}$, which can stimulate the activity of amylase in cotyledons and the conversion of insoluble starch into soluble sugars for seed germination and promote radical growth ${ }^{29,30}$. Similar results of increased emergence percentage and seedlings length, by $\mathrm{GA}_{3}$ were reported by Chauhan et al. ${ }^{24}$. However, our results were different from those of Chen et al. ${ }^{31}$ and Shaddad et al. ${ }^{32}$, who reported that $\mathrm{GA}_{3}$ had negative effects on shoot and root length in wheat and soybean (Glycine max) plants. 
The difference between these two studies probably lies in the differences in crop species and the levels of $\mathrm{GA}_{3}$. Shaddad et al. ${ }^{32}$ reported that the exogenous gibberellic acid can improve the growth and physiological parameters of the plant, which are responsible for increased fresh and dry weight of the plant.

In this study, $\mathrm{GA}_{3}$ treatment also improved relative water content (RWC). These results were in agreement with those of Ghodrat and Rousta ${ }^{33}$ and Chauhan et al. ${ }^{24}$, who reported that the RWC was increased in response to $\mathrm{GA}_{3}$ application. Soaking seeds with suitable levels of $\mathrm{GA}_{3}$ plays an important role in the induction of develop salinity tolerance such as; selective accumulation and/or exclusion of ions, ion uptake control by roots and transport into leaves, compartmentalization of ions at the cellular and whole plant levels, synthesis of compatible solutes, change in photosynthetic pathways, alteration in membrane structure, induction of antioxidative enzymes and induction of some plant hormones ${ }^{34}$. Also, overcome limitations created by the environmental stress such as nutritional imbalance, osmotic effects and ion toxicity increases salinity tolerance in the crops ${ }^{19}$. In the study, nitrogen treatment also increased RWC in the leaves of seedlings sorghum under salinity stress. The type of nitrogen sources or nitrogen level may cause the increased in RWC.

Increased in the anti-oxidative enzymes under salt stress could be suggestive of an increased of ROS and improvement of a protective mechanism to decrease oxidative harm triggered by stress in plants. In this study, salinity stress caused a significantly increased in the soluble protein content, malondialdehyde content (MDA), superoxide dismutase activity (SOD). While, catalase (CAT) and peroxidase (POD) activities was decreased with salinity levels increased. This increased in antioxidant enzyme activity might be due to the activation of plant resistance mechanisms ${ }^{1}$. The increased of accumulation protein may be due to rapid accumulation of a specific set of protein in plant ${ }^{14}$. This results are in disagreement with those of Abdoli and Shekafandeh ${ }^{35}$, Bano et al. ${ }^{36}$, Ibrahim et al. ${ }^{7}$, and Hatami et al. ${ }^{37}$. The decreased in protein content under salinity stress may be due to increased sodium content and consequently reduction in potassium concentration in the cell. Increase in SOD activity could increase the ability of the seedlings to scavenge $\mathrm{O}_{2}$ and remove the accumulation of ROS, which could cause a reduction the membrane damage. An increased of protein content and SOD activity by salinity were also reported by Ali et al. ${ }^{19}$, Zrig et al. ${ }^{38}$, and Nimir et al. ${ }^{17}$. On other hand, Dissimilar result was reported by Qiu et al. ${ }^{39}$ in wheat plant, and Sekmen et al. ${ }^{40}$ in Gypsophila oblanceolate, who mentioned that SOD, CAT and POD activities were decreased with increased salinity. The difference results between these two studies probably in the difference in crop species. This results were similar with those of Ali et al. ${ }^{19}$, and Ibrahim et al. ${ }^{7}$, who observed that salinity stress increased MDA, CAT and POD activities. In this study, salinity stress inhibited chlorophyll content as SPAD reading. The decreased in chlorophyll content under salinity stress because of the inhibitory effects of ions of several salts on the biosynthesis of different chlorophyll molecules ${ }^{41}$. These results were in accordance with Jamil and $\mathrm{Rha}^{42}$.

In this study, we observed that chlorophyll content (SPAD reading) and antioxidant enzymes activity (SOD, and POD) were decreased slightly with increased nitrogen rate. Related findings have been observed by those of Huang et al. ${ }^{43}$ and Ibrahim et al. ${ }^{7}$. In this study, CAT was initially increased with increased nitrogen rate. Related increase in the CAT activity have been also observed by those of Ibrahim et al. ${ }^{7}$, and Huang et al..$^{43}$. Moreover, MDA and protein content were increased when the plants were treated with $\mathrm{N}$. These findings are in agreement with Ibrahim et al. ${ }^{7}$.

In this study, the chlorophyll content, soluble protein, MDA content and activity of antioxidant enzymes were increased with increased $\mathrm{GA}_{3}$. Our study explained that exogenous $\mathrm{GA}_{3}$ could increase SOD, CAT and POD activities in sorghum seedlings under salt stress, and improved the seedlings ability to combat oxidative damage. This observation was contrary to the findings of Ali et al. ${ }^{19}$ and Zhu et al. ${ }^{44}$, who reported that SOD activity in salt stressed was decreased by exogenous application of hormones. Similar result was reported by Zhu et al. ${ }^{44}$ who reported that CAT and POD activities improved by $\mathrm{GA}_{3}$ amendment was beneficial for okra plants to be more efficient in breaking $\mathrm{H}_{2} \mathrm{O}_{2}$ in to $\mathrm{O}_{2}$ and $\mathrm{H}_{2} \mathrm{O}$. While, Tuna et al. ${ }^{45}$ reported that POD activity were decreased by increased exogenous $\mathrm{GA}_{3}$ at 144.3 and $288.7 \mu \mathrm{M}$ in maize plant under. The difference results in POD activity between these two studies probably lies in the difference in crop species and their activity to GA concentration $^{46}$. Related increased in MDA content have been also observed by those of Ali et al. ${ }^{8}$, who reported that MDA content was increased with increased hormone.

\section{Conclusion}

Nitrogen was beneficial or even necessary for sorghum growth and development, especially under saline conditions. Our study investigated the effects of external application of $\mathrm{GA}_{3}$ and nitrogen application on seedlings emergence percentage, seedlings growth and antioxidant enzymes of sorghum seedlings subjected to salinity. The findings from this study showed that seedling emergence percentage, seedling growth, and antioxidant enzymes were inhibited by $\mathrm{NaCl}$ salinity stress. Nitrogen and $\mathrm{GA}_{3}$ had a positive effect on seedlings emergence percentage; seedling growth and antioxidant enzymes by increased these parameters. However, from the present study, it can be concluded that nitrogen management is important when the plant growth in the salinity soil. Further, study to examine the effect of nitrogen and $\mathrm{GA}_{3}$ is needed to optimize the effectiveness of nitrogen fertilizer and seed treatments with $\mathrm{GA}_{3}$ on more cultivars of sorghum will help us to see if there is any relationship between nitrogen and $\mathrm{GA}_{3}$ and salinity tolerance of the seeds during seedling growth stages.

\section{Materials and methods}

Experimental site and soil characteristics. A controlled pot experiment was carried two times in a growth chamber at Joint International Research Laboratory of Agriculture and Agri-Product Safety of Ministry of Education of China, Yangzhou University, Yangzhou, Jiangsu Province, during 2019, to examine the impacts of GA3 and nitrogen on the emergence percentage, morphological attributes and antioxidant enzyme of the sorghum seedling under salinity. 
Plant materials. Sorghum [Sorghum bicolor (L.) Moench] seeds obtained from the Agricultural Research Institute, Sudan were used in the research. Seeds were selected for color, shape, and symmetric size. Before the study, the sorghum seeds were surface-sterilized with $1 \%$ sodium hypochlorite solution for 2 min and then were washed three times with distilled water, and then was dried with air to their original weight (50 g).

Preparation of treatment and experimental design. This study contented three factors, including three salinity concentrations at 0,100 and $200 \mathrm{mM} \mathrm{NaCl}$, three rates of nitrogen $\left(0,90\right.$ and $\left.135 \mathrm{~kg} \mathrm{~N} \mathrm{ha}^{-1}\right)$, and four gibberellic acid levels were applied: $0,144.3,288.7$ and $577.5 \mu \mathrm{M}$. The study was conducted in an RCBD as a factorial experiment arranged in a split-split-plot with three replications. The main plots included three different salinity levels, the subplots included three different levels of nitrogen fertilizer as urea and the sub-sub-plot included four levels of gibberellic acid. Before seed planting, seeds $(50 \mathrm{~g})$ were soaked in $500 \mathrm{~mL}$ of one of the gibberellic acid solutions under dark conditions for $12 \mathrm{~h}$, while the control was treated with distilled water. The seeds were dried with forced air for $48 \mathrm{~h}$ to their original weight to safe moisture content of seeds. The pots used in this study are $9.5 \mathrm{~cm}$ in diameter and $8.5 \mathrm{~cm}$ in depth. Each pot was filled with $400 \mathrm{~g}$ washed sand. Nitrogen treatment was made by nitrogen solution at the first irrigation with the same amount $(10 \mathrm{~mL})$ of 0,90 and $135 \mathrm{~kg} \mathrm{~N} \mathrm{ha}^{-1}$. Urea is the source of nitrogen fertilizer. Salinity treatment was made by the $\mathrm{NaCl}$ solution in each pot by the first irrigation with the same amount $(80 \mathrm{~mL})^{2}$. Ten seeds were sown in each pot at $2 \mathrm{~cm}$ in depth. All the pots were placed in the growth chamber (Model PYX-300G-B, Yangzhou Yiwei Automatic Instrument Co. Ltd, Jiangsu, China) for three weeks at $30 / 25^{\circ} \mathrm{C}$ day/night. The relative humidity was maintained at $55-60 \%$ and $14 / 10 \mathrm{~h}$ day/ night under a photoactive radiation (PAR) of $500 \mathrm{~W} \mathrm{~m}^{-221,47}$.

Measurements. Emergence percentage (EP\%). Seedlings were considered emerged when the coleoptiles were visible above the substratum surface. After 10 days, seedling emergence percentage was calculated with the following formula:

$$
\mathrm{EP} \%=\frac{\text { No. of emerged seedlings after } 10 \text { days }}{\text { Total No. of seeds on pot }} \times 100
$$

Seedlings growth attributes. At 21 days after planting, the seedlings of each pot were harvested and washed. Seedling growth parameters were measured including seedling length, fresh weight (FW) and dry weight (DW). DW was recorded after dry the seedlings in the oven at $80^{\circ} \mathrm{C}$ for $80 \mathrm{~h}$.

Relative water content. Relative water content (RWC) was measured according to the described by Mäkelä et al. ${ }^{48}$. Leaflet samples were harvested from the three plants. The FW was determined, and the leaves were kept in water for $8 \mathrm{~h}$ for saturation weight measurement. The samples were dried in a hot air oven at $80{ }^{\circ} \mathrm{C}$ for $72 \mathrm{~h}$ to determine DW. The RWC was calculated as the following formula:

$$
\mathrm{RWC}=\frac{[\text { Fresh weight }- \text { Dry weight }]}{[\text { Saturation weight }- \text { Dry weight }]} \times 100
$$

Chlorophyll content (SPAD reading). Eighteen days after planting, the penultimate leaves of each seedling in each pot were used for SPAD determination with a chlorophyll meter (SPAD-502, chlorophyll meter, Minolta Camera Co., Ltd., Japan). The SPAD reading was recorded for three seedlings. The average of SPAD readings of the seedlings of each pot was calculated.

Determination of biochemical attribute. The soluble protein content was determined according to Bradford ${ }^{49}$. The peroxide (POD) activity was assayed according to the method of $\mathrm{Xu}$ and $\mathrm{Ye}^{50}$. The activity of superoxide dismutase (SOD) and catalase (CAT) was measured following the method of Janmohammadi et al. ${ }^{51}$. The malondialdehyde (MDA) content was determined following the method of Zhang et al. ${ }^{52}$.

Statistical analysis. The data of each variable were statistically analyzed of variance for RCBD as a factorial design with the statistical package of MSTATC ${ }^{53}$. When F values were significant, means were separated by the least significant difference (LSD) test $\left(\mathrm{P} \leq 0.05\right.$ probability) as described by Snedecor and Cochran ${ }^{54}$.

Received: 5 September 2020; Accepted: 23 December 2020

Published online: 23 March 2021

\section{References}

1. Ibrahim, M. E. H. et al. Nitrogen fertilizer alleviated negative impacts of nacl on some physiological parameters of wheat. Pak. J. Bot. 50, 2097-2104 (2018).

2. Ibrahim, H., Zhu, X., Hu, X., Zhou, G. \& Abidallhaa, E. H. M. A. Effects of nitrogen on seedling growth of wheat varieties under salt stress. J. Agric. Sci. 8, 131-146 (2016)

3. Ibrahim, H., Zhu, X., Zhou, G., Nimir, A. \& Eltyb, N. Comparison of germination and seedling characteristics of wheat varieties from China and Sudan under salt stress. Agron. J. 108, 85-92 (2016).

4. Kumari, P., Pahuja, S. K., Arya, S. \& Patil, J. V. Broadening the Genetic Base of Grain Cereals 163-203 (Springer, New York, 2016).

5. Nimir, N. E. A. et al. Effect of foliar application of GA3, kinetin, and salicylic acid on ions content, membrane permeability, and photosynthesis under salt stress of sweet sorghum [Sorghum bicolor (L.) Moench]. Can. J. Plant Sci. 97, 525-535 (2016). 
6. Machado, R. \& Serralheiro, R. Soil salinity: effect on vegetable crop growth. Management practices to prevent and mitigate soil salinization. Horticulturae 3, 30-42 (2017).

7. Ibrahim, M. E. H. et al. Nitrogen fertilizer reduces the impact of sodium chloride on wheat yield. Agron. J. 110, 1-7 (2018).

8. Ali, A. Y. A. et al. Exogenous jasmonic acid and humic acid increased salinity tolerance of sorghum. Agron. J. 112, 1-14 (2020).

9. Farhangi, A. S. \& Ghassemi, G. K. How can salicylic acid and jasmonic acid mitigate salt toxicity in soybean plants. Ecotoxicol. Environ. Saf. 147, 1010-1016 (2018).

10. Dong, F. et al. Effects of nitrogen supply on flavonol glycoside biosynthesis and accumulation in tea leaves (Camellia sinensis L.). Plant Physiol. Biochem. 138, 48-57 (2019).

11. Ahmad, I. et al. Response of boll development to macronutrients application in different cotton genotypes. Agronomy 9, 322-344 (2019).

12. Zhang, X., Huang, G., Bian, X. \& Zhao, Q. Effects of root interaction and nitrogen fertilization on the chlorophyll content, root activity, photosynthetic characteristics of intercropped soybean and microbial quantity in the rhizosphere. Plant Soil Environ. 59, 80-88 (2013).

13. Kandil, A. A., Sharief, A. E., Abido, W. A. E. \& Awed, A. M. Effect of gibberellic acid on germination behaviour of sugar beet cultivars under salt stress conditions of Egypt. Sugar Tech. 16, 211-221 (2014).

14. Zhou, G., Nimir, N., Lu, S., Zhai, F. \& Wang, Y. Gibberellic acid and salinity affected growth and antioxidant enzyme activities in castor bean plants at early growth stage. Agron. J. 106, 1340-1348 (2014).

15. Mishra, J. S., Kumar, R. \& Rao, S. S. Performance of sweet sorghum (Sorghum bicolor L.) cultivars as a source of green fodder under varying levels of nitrogen in semi-arid tropical India. Sugar Tech. 19, 532-538 (2017).

16. Maswada, H. F., Djanaguiraman, M. \& Prasad, P. V. V. Seed treatment with nano-iron(III) oxide enhances germination, seeding growth and salinity tolerance of sorghum. J. Agron. Crop Sci. 204, 577-587 (2018).

17. Nimir, N. E. A. et al. Comparative effects of gibberellic acid, kinetin and salicylic acid on emergence, seedling growth and the antioxidant defence system of sweet sorghum (Sorghum bicolor L.) under salinity and temperature stresses. Crop Pasture Sci. 66, $145-157$ (2015).

18. Kandil, A. A., Sharief, A. E., Abido, W. A. E. \& Ibrahim, M. M. Effect of salinity on seed germination and seedling characters of some forage sorghum cultivars. Int. J. Agric. Sci. 4, 306-311 (2012).

19. Ali, A. Y. A. et al. Ameliorative effects of jasmonic acid and humic acid on antioxidant enzymes and salt tolerance of forage sorghum under salinity conditions. Agron. J. 111, 3099-3108 (2019).

20. Farooq, M., Hussain, M., Wakeel, A. \& Siddique, K. H. M. Salt stress in maize: Effects, resistance mechanisms, and management: A review. Agron. Sustain. Dev. 35, 461-481 (2015).

21. Ibrahim, M. E. H. et al. Mitigation effect of biochar on sorghum seedling growth under salinity stress. Pak. J. Bot. 53, 1-6 (2020).

22. Khan, W. D., Aziz, T., Waraich, E. A. \& Khalid, M. Silicon application improves germination and vegetative growth in maize grown under salt stress. Pak. J. Agric. Sci. 52, 937-944 (2015).

23. Ramezani, E., Sepanlou, M. G. \& Badi, H. A. N. The effect of salinity on the growth, morphology and physiology of Echium amoenum Fisch. \& Mey. Afr. J. Biotechnol. 10, 8765-8773 (2011).

24. Chauhan, A. et al. Influence of gibberellic acid and different salt concentrations on germination percentage and physiological parameters of oat cultivars. Saudi J. Biol. Sci. 26, 1298-1304 (2019).

25. Dheeba, B., Sampathkumar, P. \& Kannan, K. Fertilizers and mixed crop cultivation of chromium tolerant and sensitive plants under chromium toxicity. J. Toxicol. 9, 51-60 (2015).

26. Fallahi, J. \& Khajeh, H. M. Effects of applying various levels of nitrogen on parent plants on the resistance to salinity stress in achieved seeds in Triticum aestivum (L.) cv. Gaskojen at germination period. J. Agric. Technol. 7, 1743-1754 (2011).

27. Xiong, F., Yu, X., Zhou, L. \& Wang, Z. Effect of nitrogen application at the booting stage on wheat progeny seed germination and seedling growth. J. Plant Stud. 2, 158-166 (2013).

28. Lay, P., Basvaraju, G. V., Sarika, G. \& Amrutha, N. Effect of seed treatments to enhance seed quality of papaya (Carica papaya L.) cv. Surya. Glob. J. Biol. Agric. Health Sci. 2, 221-225 (2013).

29. Palepad, K. B., Bharad, S. G. \& Bansode, G. S. Effect of seed treatments on germination, seedling vigour and growth rate of custard apple (Annona squamosa L.). J. Pharm. Phytochem. 6, 20-23 (2017).

30. Ibrahim, M. E. H. et al. Response of some wheat varieties to gibberellic acid under saline conditions. Agrosyst. Geosci. Environ. 2, $1-7$ (2019).

31. Chen, L., Hao, L., Condon, A. \& Hu, Y.-G. Exogenous $\mathrm{GA}_{3}$ application can compensate the morphogenetic effects of the GAresponsive dwarfing gene Rht12 in bread wheat. PLOS ONE 9, 1-11 (2014).

32. Shaddad, M. A. K. \& Mostafa, D. Role of gibberellic acid $\left(\mathrm{GA}_{3}\right)$ in improving salt stress tolerance of two wheat cultivars. Int. J. Plant Physiol. Biochem. 5, 50-57 (2013).

33. Ghodrat, V. \& Rousta, M. J. Effect of priming with gibberellic acid (GA3) on germination and growth of corn (Zea mays L.) under saline conditions. Int. J. Agric. Crop. Sci. 4, 883-885 (2012).

34. Pirasteh-Anosheh, H., Ranjbar, G., Pakniyat, H. \& Emam, Y. Physiological mechanisms of salt stress tolerance in plants: An overview. Plant Environ. Interact. 1, 141-160 (2016).

35. Abdoli, N. R. \& Shekafandeh, A. Salt stress-induced changes in leaf antioxidant activity, proline and protein content in 'Shah Anjir' and 'Anjir Sabz'fig seedlings. Int. J. Hortic. Sci. Technol. 1, 121-129 (2014).

36. Bano, S., Ashraf, M. \& Akram, N. A. Salt stress regulates enzymatic and nonenzymatic antioxidative defense system in the edible part of carrot (Daucus carota L.). J. Plant Interact. 9, 324-329 (2014).

37. Hatami, E., Shokouhian, A. A., Ghanbari, A. R. \& Naseri, L. A. Alleviating salt stress in almond rootstocks using of humic acid. Sci. Hortic. 237, 296-302 (2018).

38. Zrig, A., Mohamed, H., Ben Tounekti, T., Ahmed, S. O. \& Khemira, H. Differential responses of antioxidant enzymes in salt-stressed almond tree grown under sun and shade conditions. J. Plant Sci. Res 2, 1-10 (2015).

39. Qiu, Z., Guo, J., Zhu, A., Zhang, L. \& Zhang, M. Exogenous jasmonic acid can enhance tolerance of wheat seedlings to salt stress. Ecotoxicol. Environ. Saf. 104, 202-208 (2014).

40. Sekmen, A. H., Turkan, I., Tanyolac, Z. O., Ozfidan, C. \& Dinc, A. Different antioxidant defense responses to salt stress during germination and vegetative stages of endemic halophyte Gypsophila oblanceolata BARK. Environ. Exp. Bot. 77, 63-76 (2012).

41. Kaya, C. et al. Exogenous application of nitric oxide and thiourea regulates on growth and some key physiological processes in maize (Zea mays L.) plants under saline stress. Toprak Dergisi 1, 61-66 (2015).

42. Jamil, M. \& Rha, E. S. The effect of salinity $(\mathrm{NaCl})$ on the germination and seedling of sugar beet (Beta vulgaris $\mathrm{L}$.) and cabbage (Brassica oleracea L.). Plant Resour. 7, 226-232 (2004).

43. Huang, Z. A., Jiang, D. A., Yang, Y., Sun, J. W. \& Jin, S. H. Effects of nitrogen deficiency on gas exchange, chlorophyll fluorescence, and antioxidant enzymes in leaves of rice plants. Photosynthetica 42, 357-364 (2004).

44. Zhu, G. et al. Gibberellic acid amended antioxidant enzyme and osmotic regulation to improve salt tolerance of okra at early growth stage. Int. J. Agric. Biol. 22, 270-276 (2019).

45. Tuna, A. L., Kaya, C., Dikilitas, M. \& Higgs, D. The combined effects of gibberellic acid and salinity on some antioxidant enzyme activities, plant growth parameters and nutritional status in maize plants. Environ. Exp. Bot. 62, 1-9 (2008).

46. Hasanuzzaman, M., Nahar, K. \& Fujita, M. Plant response to salt stress and role of exogenous protectants to mitigate salt-induced damages. in Ecophysiology and Responses of Plants Under Salt Stress 25-87 (Springer, 2013). 
47. Ibrahim, M. E. H. et al. Biochar improved sorghum germination and seedling growth under salinity stress. Agron. J. 112, 911-920 (2020).

48. Makela, P., Munns, R., Colmer, T. D., Condon, A. G. \& Peltonen, S. P. Effect of foliar applications of glycinebetaine on stomatal conductance, abscisic acid and solute concentrations in leaves of salt-or drought-stressed tomato. Funct. Plant Biol. 25, 655-663 (1998).

49. Bradford, M. M. A rapid and sensitive method for the quantitation of microgram quantities of protein utilizing the principle of protein-dye binding. Anal. Biochem. 72, 248-254 (1976).

50. Xu, L. L. \& Ye, M. B. A measurement of peroxidase activity using continuous recording method. J. Nanjing Agric. Univ. 12, $82-83$ (1989).

51. Janmohammadi, M., Abbasi, A. \& Sabaghnia, N. Influence of $\mathrm{NaCl}$ treatments on growth and biochemical parameters of castor bean (Ricinus communis L.). Acta Agric. Slovenica 99, 31-40 (2012).

52. Zhang, S., Hu, J., Zhang, Y., Xie, X. J. \& Knapp, A. Seed priming with brassinolide improves lucerne (Medicago sativa L.) seed germination and seedling growth in relation to physiological changes under salinity stress. Aust. J. Agric. Res. 58, 811-815 (2007).

53. Freed, R. et al. MSTAT-C: A microcomputer program for the design, management, and analysis of agronomic research experiments (Michigan State University, 1991).

54. Snedecor, G. W. \& Cochran, W. G. Statistical Methods (Iowa State University Press, 1980).

\section{Acknowledgements}

This study was supported in part by Jiangsu Provincial Forestry Innovation and Extension Fund (LYKJ [2019]47 and National Key R \& D Program of China (2018YFE0108100).

\section{Author contributions}

Conceptualization, Adam Y.A.A.; methodology, take measurement, visualization, writing original draft preparation, and software, Adam Y.A.A. and Muhi E.H.I.; data curation and analysis, Aboagla M.I.E., Mohamed S.E.S., Safiya B.M.E. and Ebthal G.I.S.; take measurement and investigation, Nimir E.A.N., Guanglong Z. and Xiurong J.; review the manuscript, Guishang Z.; writing review and editing, visualization, supervision, project administration and funding acquisition. All authors have read and agreed to the published version of the manuscript.

\section{Competing interests}

The authors declare no competing interests.

\section{Additional information}

Correspondence and requests for materials should be addressed to G.Z.

Reprints and permissions information is available at www.nature.com/reprints.

Publisher's note Springer Nature remains neutral with regard to jurisdictional claims in published maps and institutional affiliations.

(c) (i) Open Access This article is licensed under a Creative Commons Attribution 4.0 International License, which permits use, sharing, adaptation, distribution and reproduction in any medium or format, as long as you give appropriate credit to the original author(s) and the source, provide a link to the Creative Commons licence, and indicate if changes were made. The images or other third party material in this article are included in the article's Creative Commons licence, unless indicated otherwise in a credit line to the material. If material is not included in the article's Creative Commons licence and your intended use is not permitted by statutory regulation or exceeds the permitted use, you will need to obtain permission directly from the copyright holder. To view a copy of this licence, visit http://creativecommons.org/licenses/by/4.0/.

(C) The Author(s) 2021 